\title{
Childhood Grade II Meningioma
}

National Cancer Institute

\section{Source}

National Cancer Institute. Childhood Grade II Meningioma. NCI Thesaurus. Code C71301.

A grade II meningioma that occurs during childhood. 